University of Nebraska - Lincoln

DigitalCommons@University of Nebraska - Lincoln

July 2005

\title{
LOSS OF PHOSPHORUS BY RUNOFF FOR AGRICULTURAL WATERSHEDS
}

\author{
M. A. Elrashidi \\ USDA-NRCS \\ M. D. Mays \\ USDA-NRCS \\ J. Harder \\ USDA-NRCS \\ D. Schroeder \\ USDA-NRCS \\ P. Brakhage \\ Nebraska Department of Environmental Quality, Lincoln, NE \\ See next page for additional authors
}

Follow this and additional works at: https://digitalcommons.unl.edu/usdaarsfacpub

Part of the Agricultural Science Commons

Elrashidi, M. A.; Mays, M. D.; Harder, J.; Schroeder, D.; Brakhage, P.; Peaslee, S.; Seybold, C.; and Schaecher, C., "LOSS OF PHOSPHORUS BY RUNOFF FOR AGRICULTURAL WATERSHEDS" (2005). Publications from USDA-ARS / UNL Faculty. 153.

https://digitalcommons.unl.edu/usdaarsfacpub/153

This Article is brought to you for free and open access by the U.S. Department of Agriculture: Agricultural Research Service, Lincoln, Nebraska at DigitalCommons@University of Nebraska - Lincoln. It has been accepted for inclusion in Publications from USDA-ARS / UNL Faculty by an authorized administrator of DigitalCommons@University of Nebraska - Lincoln. 


\section{Authors}

M. A. Elrashidi, M. D. Mays, J. Harder, D. Schroeder, P. Brakhage, S. Peaslee, C. Seybold, and C. Schaecher 


\title{
LOSS OF PHOSPHORUS BY RUNOFF FOR AGRICULTURAL WATERSHEDS
}

\author{
M. A. Elrashidi', M. D. Mays', J. Harder², D. Schroeder², P. Brakhage?3, S. Peaslee', \\ C. Seybold', and C. Schaecher ${ }^{1}$
}

The loss of nutrients in runoff from agricultural land is a major cause of poor surface water quality in the United State. Scientists (NRCS) developed a technique to estimate the impact of agricultural watersheds on natural water resources. The objectives of this study were to apply this technique on the Wagon Train (WT) watershed to predict (1) loss of water by surface runoff, (2) loss of phosphorus $(P)$ from soils by runoff and $P$ loading for WT reservoir. The annual loss of water by runoff was estimated at 4.32 million $\mathrm{m}^{3}$. The USGS data for a 50-year period (1951 to 2000) indicated that the average annual inflow for WT reservoir was 4.25 million $\mathrm{m}^{3}$. The predicted annual $P$ loss by runoff was $844 \mathrm{~kg}$ and could be considered as the annual loading for WT reservoir. The predicted $P$ concentration in the runoff water at field sites was $196 \mu \mathrm{g} / \mathrm{L}$. Phosphorus concentration observed in major streams at the beginning of spring (March) ranged from $99 \mu \mathrm{g} / \mathrm{L}$ to $240 \mu \mathrm{g} / \mathrm{L}$ with an average of 162 $\mu \mathrm{g} / \mathrm{L}$ (S.D. $=40 \mu \mathrm{g} / \mathrm{L}$ ), and the average $P$ concentration in water samples taken from different locations in the reservoir was $140 \mu \mathrm{g} / \mathrm{L}$. Phosphorus uptake by algae, weeds and aquatic plants, as well as high $\mathrm{pH}$ in the reservoir and streams might explain the slight drop of $P$ concentration in waters. Further, the average $P$ concentration observed in the main stream samples for the entire rainy season (March through October), ranged between 157 and $346 \mu \mathrm{g} / \mathrm{L}$ with an average of $267 \mu \mathrm{g} / \mathrm{L}$ (S.D. $=65$ $\mu \mathrm{g} / \mathrm{L}$ ). Application of $\mathrm{P}$ fertilizers (April/May) for summer crops might explain the increase in $\mathbf{P}$ concentration. When factors affecting $\mathbf{P}$ concentration in streams are considered, the technique could provide a reasonable estimation of $\mathbf{P}$ concentration in stream water. (Soil Science 2005;170:543-558)

Key words: Agricultural watershed, anion exchange resin, phosphorus release characteristics, runoff phosphorus, runoff water.

W HEN phosphorus (P) applied to agricultural land by fertilizers and manure application exceeds $\mathrm{P}$ removal by harvested crops, repeated applications can lead to an accumulation in surface soils. Carpenter et al., (1998) reported that during the period of 1950 to 1995 , an average $P$ surplus of $26 \mathrm{~kg} / \mathrm{ha}$ per year accumulated on agricultural soils in the United States.

USDA-NRCS, National Soil Survey Center, 100 Centennial Mall North, Lincoln, NE 68508-3866. Dr. Elrashidi is corresponding author. E-mail: moustafa.elrashidi@usda.gov

2USDA-NRCS, Lincoln, NE 68516.

${ }^{3}$ Nebraska Department of Environmental Quality, Lincoln, NE 68509 ;

Received Dec. 9, 2004; accepted March 24, 2005.

DOI: $10.1097 / 01.55 .0000175340 .84421$, ec
The accumulation increases the potential for $P$ movement from soils through runoff and leaching to pollute surface and ground waters. The downward transport of $\mathrm{P}$ through the vadose zone is limited because of the high sorption capacity for most acidic and alkaline soils (Lindsay, 1979). Except for sandy soils in high rainfall areas, leaching $\mathrm{P}$ from agricultural land plays an insignificant role in contaminating fresh waters (Elrashidi et al., 2001; Novak et al., 2000). On the other hand, surface runoff from agricultural land is considered a major nonpoint $\mathrm{P}$ source of pollution for many lakes, rivers, estuaries, and coastal oceans (Carpenter et al., 1998).

Phosphorus is lost from agricultural land to surface water bodies in sediment-bound and 
dissolved forms. Sediment-bound $\mathrm{P}$ includes $\mathrm{P}$ associated with minerals and organic matter. Dissolved $\mathrm{P}$ constitutes 10 to $40 \%$ of the $\mathrm{P}$ transported from most cultivated soils to water bodies through runoff (Sharpley et al., 1992). Sharpley et al. (1992) reported that surface runoff from grassland, forest, and cultivated soils carries little sediment and carries dominantly dissolved forms of $\mathrm{P}$. Unlike sediment-bound $\mathrm{P}$, dissolved $P$ is readily bioavailable and thus is the main cause of eutrophication.

Dissolved $\mathrm{P}$ concentration as low as $20 \mu \mathrm{g} / \mathrm{L}$ in water can cause eutrophication (Sharpley et al., 1999; USEPA, 1996). There is no regulatory threshold for $\mathrm{P}$ concentration in surface or ground waters. However, the USEPA (1986) recommended a limit of $50 \mu \mathrm{g} / \mathrm{L}$ for total $\mathrm{P}$ in streams that enter lakes and $100 \mu \mathrm{g} / \mathrm{L}$ for total $\mathrm{P}$ in flowing water to minimize the impact on freshwater bodies.

The transport of soil $\mathrm{P}$ from agricultural land to surface waters depends on many factors including climate, soil type and hydrology, soil $\mathrm{P}$ content, agronomic practices, and landscape (Lemunyon and Gilbert, 1993). Most of these factors were considered by the NRCS technique (Elrashidi et al., 2003) to estimate $P$ release from soils by rainfall and quantify runoff $P$ for agricultural land. A brief description of the technique is outlined in the Materials and Methods section.

Eutrophication of some freshwater bodies in Wagon Train (WT) watershed (Lancaster County, Nebraska) raised public concern of the role of agricultural land as nonpoint $P$ source of contamination. The overall goal of the project was to apply the NRCS technique in evaluating the role of agricultural land and how it might affect surface water bodies in WT watershed. The objectives were to estimate (1) water loss from soils by runoff and (2) P loss from soils by runoff and loading in WT reservoir.

\section{MATERIALS AND METHODS}

\section{Wagon Train Watershed}

Wagon Train (WT) watershed lake is a 128 hectare (315-acre) reservoir located on the Hickman Branch of Salt Creek (Platte River Basin) in Lancaster County, Nebraska (Fig. 1). The reservoir was constructed primarily as a flood control structure by the U.S. Army Corps of Engineers in 1962. The total drainage area encompasses 9,984 acres (4042 hectare) of agricultural land. Most of the area (70\%) is cultivated with crops [soybean (glycine willd), corn (zea mays $L$.), wheat (triticum aestivum L.), sunflower (helianthus L.), and alfalfa (medicago sativa L.)]. The rest of the watershed is covered with grassland while forest land, wetland, and urban development account for small areas.

The watershed topography is moderately sloping and most soils are well drained. The land relief consists of uplands, stream terraces and bottom lands. There are $53 \mathrm{~km}$ (33 miles) of streams in the watershed and 40 ponds ranging in size from 0.3 to 6.5 acres ( 0.12 to 2.6 hectare). Overland flow enters the reservoir through intermittent tributaries. From the dam, the water flows into the Hickman Branch of Salt Creek, which flows west and north to Lincoln and eventually to the Platte River near Ashland.

The watershed has three major soil associations. The Wymore-Pawnee association soils are deep, nearly level to sloping soils, located on ridge tops and side slopes. The Pawnee-Burchard association soils are deep, gently to steeply sloping, loamy and clayey upland soils that developed in glacial till. The Kennebec-NodawayZook association soils are deep, nearly level or gently sloping silty soils formed in alluvium on flood plains.

We used soil associations on the general soil map in the Soil Survey Report of Lancaster County, Nebraska (Brown et al., 1980), to determine the major soil series and phases in WT watershed. Nine soil series (Wymore, Pawnee, Nodaway, Sharpsburg, Mayberry, Colo, Judson, Burchard, and Kennebec; Table 1) account for $96.1 \%$ of the agricultural land. Nearly threequarters of the watershed consist of Wymore and Pawnee soils.

\section{Soil and Water Sampling}

Soil sampling included each of three widely existent phases of Wymore (Wymore-WtB, $\mathrm{WtC} 2$, and $-\mathrm{WtD} 3$ ), and two phases of Pawnee (Pawnee- $\mathrm{PaC} 2$ and $-\mathrm{PaD} 2$ ) along with the other seven soil series. This approach gave a total of 12 soil map units. Recently, updated soil survey activities have split Sharpsburg into three series (Tomek, Yutan, and Aksarben). The new classification, however, should not affect results given in this study.

To obtain representative soil samples, we divided the watershed area into six sections. For each of the 12 soil map units, one sample was 


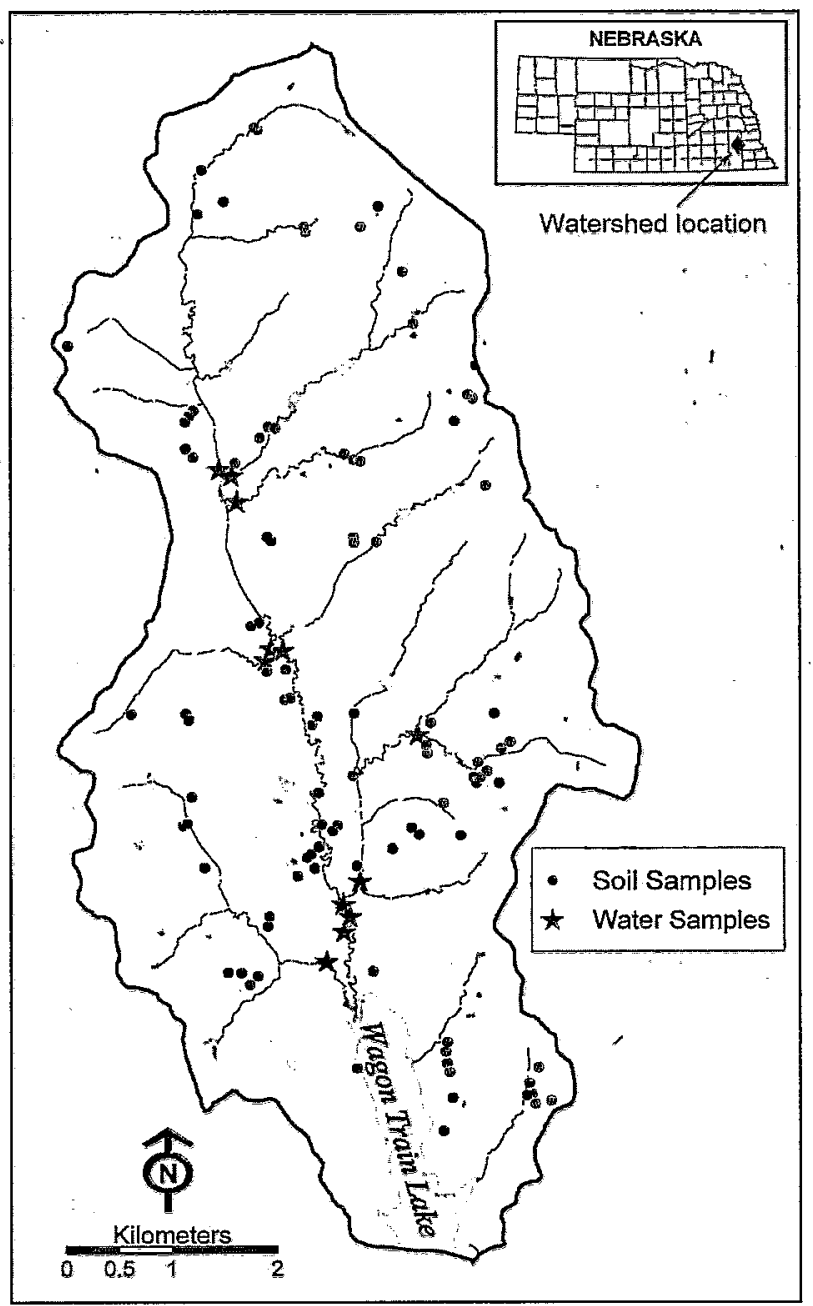

Fig. 1. Soil and water sampling locations in Wagon Train watershed, Lancaster County, Nebraska.

taken from cropland within each of the six sections of the watershed. For each soil map unit, however, only two grassland samples were collected because of the limited area covered with grass in the watershed. Thus, in total, 72 soil samples from cropland and 24 from grassland were collected. At the randomly selected sampling sites, three cores were taken from the top $30-\mathrm{cm}$ soil layer and mixed thoroughly in a stainless steel tray. Approximately, a $2-\mathrm{kg}$ composite sample was packed in a plastic bag and sealed. Sampling was completed during April of 2003 before fertilizer application for the summer crop.

Many small streams receive surface water runoff from the agricultural land in the watershed. Eventually, streams located northerly of the reservoir join in a single stream that runs southerly about $0.5 \mathrm{~km}$ before entering the reservoir near the north edge. Water samples taken along the main stream were assumed to represent the surface water runoff generated from the entire watershed.

Most of the surface water runoff from the agricultural land in WT watershed and water inflow for WT reservoir are expected during the rainy season in the spring, summer, and early fall (March through October). In the middle of March, water samples were collected at 12 locations for major streams in the watershed (Fig. 1). These samples include three locations along the main stream before entering the reservoir. Phosphorus analysis for major streams proved that samples taken from the main stream are good representative for runoff generated from the entire watershed. Accordingly, during 
the period from April to October, monthly samples were collected only from the three locations along the main stream.

All water samples were taken from streams under base flow conditions to ensure a clear runoff with almost no suspended particulates. Samples were collected (grab) in midstream, by using 1-L polyethylene bottles that have been rinsed twice with stream water before sample collection. The water samples were taken immediately to the laboratory and refrigerated at $4{ }^{\circ} \mathrm{C}$. The water analysis was completed within 1 week. The soil and water sampling locations are shown in Fig. 1.

\section{Soil and Water Analysis}

Soil samples were analyzed on air-dried $<2-$ $\mathrm{mm}$ soil by methods described in Soil Survey Investigations Report (SSIR) No. 42 (USDA/ NRCS, 1996). Alphanumeric codes in parentheses next to each method represent specific standard operating procedures. Particle-size analysis was performed by sieve and pipette method (3A1). Cation exchange capacity (CEC) was conducted by $\mathrm{NH}_{4} \mathrm{OAc}$ buffered at $\mathrm{pH} 7.0$ (5A8b). Total carbon (C) content was determined by dry combustion (6A2f), and $\mathrm{CaCO}_{3}$ equivalent was estimated by electronic manometer method $(6 \mathrm{E} 1 \mathrm{~g})$. Organic $\mathrm{C}$ in soil was estimated from both the total-, and $\mathrm{CaCO}_{3}-\mathrm{C}$. Soil $\mathrm{pH}$ was measured in a $1: 1$ soil/water suspension (8C1f). Classification and selected properties for soils under crop and grass in WT watershed are given in Table 1.

Soil $\mathrm{P}$ was determined by Olsen (Olsen et al., 1954), Bray1 (Bray and Kurtz, 1945), and Mehlich3 (Mehlich, 1984) methods. Anion exchange resin (AER) extractable-P was determined by the Soil Survey Laboratory method (Elrashidi et al., 2003). Phosphorus measured by these methods ( $\mathrm{mg} / \mathrm{kg}$ soil) for soils under crop and grass in WT watershed are presented in Table 2.

\section{TABLE 1}

Classification and some properties for the 12 major soils under crop and grass cover in Wagon Train watershed, Lancaster County, Nebraska

\begin{tabular}{|c|c|c|c|c|c|c|}
\hline $\begin{array}{l}\text { Soil } \\
\text { (map unit) }\end{array}$ & Classification & Land use & Clay (\%) & OM (\%) & $\begin{array}{c}\mathrm{CEC} \\
(\mathrm{Cmol} / \mathrm{kg}) \\
\end{array}$ & $\mathrm{pH}$-water \\
\hline \multirow[t]{2}{*}{ Wymore $(\mathrm{W} t \mathrm{~B})$} & \multirow{2}{*}{$\begin{array}{l}\text { Fine, smectitic, } \\
\text { mesic Aquertic Argiudolls }\end{array}$} & Cropland & 37.3 & 2.14 & 25.9 & 5.56 \\
\hline & & Grassland & 32.9 & 2.44 & 25.7 & 5.90 \\
\hline \multirow[t]{2}{*}{ Wymore (WtC2) } & \multirow{2}{*}{$\begin{array}{l}\text { Fine, smectitic, } \\
\text { mesic Aquertic Argiudolls }\end{array}$} & Cropland & 37.9 & 2.23 & 26.5 & 5.70 \\
\hline & & Grassland & 35.6 & 3.46 & 28.2 & 5.80 \\
\hline \multirow[t]{2}{*}{ Wymore (WtD3) } & \multirow{2}{*}{$\begin{array}{l}\text { Fine, smectitic, } \\
\text { mesic Aquertic Argiudolls ' }\end{array}$} & Cropland & 41.2 & 2.16 & 29.3 & 5.85 \\
\hline & & Grassland & 34.2 & 2.78 & 28.9 & . 6.40 \\
\hline \multirow[t]{2}{*}{ Pawnee $(\mathrm{PaC} 2)$} & \multirow{2}{*}{$\begin{array}{l}\text { Fine, smectitic, mesic } \\
\text { Oxyaquic Vertic Argiudolls }\end{array}$} & Cropland & 35.2 & 1.94 & 24.9 & 5.64 \\
\hline & & Grassland & 29.3 & 2.38 & 21.7 & 5.55 \\
\hline \multirow[t]{2}{*}{ Pawnee $(\mathrm{PaD} 2)$} & \multirow{2}{*}{$\begin{array}{l}\text { Fine, smectitic, mesic } \\
\text { Oxyaquic Vertic Argiudolls }\end{array}$} & Cropland & 34.9 & 1.85 & 24.5 & 5.79 \\
\hline & & Grassland & 34.7 & 2.39 & 25.5 & 6.10 \\
\hline \multirow[t]{2}{*}{ Nodaway (No, Ns) } & \multirow{2}{*}{$\begin{array}{l}\text { Fine-silty, mixed, superactive, } \\
\text { nonacid, mesic Mollic } \\
\text { Udifluvents }\end{array}$} & Cropland & 29.4 & 2.08 & 24.4 & 6.58 \\
\hline & & Grassland & 30.1 & 2.97 & 26.4 & 6.25 \\
\hline \multirow{2}{*}{$\begin{array}{l}\text { Sharpsburg } \\
\text { (ShC, ShD, ShD2) }\end{array}$} & \multirow{2}{*}{$\begin{array}{l}\text { Fine, smectitic, } \\
\text { mesic Typic Argiudolls }\end{array}$} & Cropland & 39.7 & 1.94 & 27.6 & 5.70 \\
\hline & & Grassland & 37.4 & 2.05 & 27.0 & 6.15 \\
\hline \multirow{2}{*}{$\begin{array}{l}\text { Mayberry } \\
\qquad(\mathrm{MeC} 2, \mathrm{MeD} 2, \mathrm{MhC} 3)\end{array}$} & \multirow{2}{*}{$\begin{array}{l}\text { Fine, smectitic, } \\
\text { mesic Aquertic Argiudolls }\end{array}$} & Cropland & 31.8 & 1.96 & 22.8 & 5.99 \\
\hline & & Grassland & 26.0 & 2.08 & 20.4 & 6.50 \\
\hline \multirow[t]{2}{*}{ Colo (Co, Cp) } & \multirow{2}{*}{$\begin{array}{l}\text { Fine-silty, mixed, superactive, } \\
\text { mesic Cumulic Endoaquolls }\end{array}$} & Cropland & 32.1 & 2.13 & 25.0 & 6.30 \\
\hline & & Grassland & 29.0 & 2.95 & 26.1 & 6.10 \\
\hline \multirow[t]{2}{*}{ Judson (JuC) } & \multirow{2}{*}{$\begin{array}{l}\text { Fine-silty, mixed, superactive, } \\
\text { mesic Cumulic Hapludolls }\end{array}$} & Cropland & 32.0 & 2.26 & 24.8 & 6.05 \\
\hline & & Grassland & 30.5 & 3.06 & 24.0 & 6.00 \\
\hline \multirow{2}{*}{$\begin{array}{l}\text { Burchard } \\
\qquad(\mathrm{BpF}, \mathrm{BrD}, \mathrm{BrE})\end{array}$} & \multirow{2}{*}{$\begin{array}{l}\text { Fine-loamy, mixed, } \\
\text { superactive, mesic Typic } \\
\text { Argiudolls }\end{array}$} & Cropland & 29.8 & 1.89 & 21.7 & 5.96 \\
\hline & & Grassland & 30.1 & 2.99 & 23.1 & 7.00 \\
\hline \multirow[t]{2}{*}{ Kennebec $(\mathrm{Ke})$} & \multirow{4}{*}{$\begin{array}{l}\text { Fine-silty, mixed, superactive, } \\
\text { mesic Cumulic Hapludolls }\end{array}$} & Cropland & 27.6 & 1.94 & 20.7 & 5.95 \\
\hline & & Grassland & 24.7 & 2.09 & 19.5 & 6.10 \\
\hline \multirow[t]{2}{*}{ Average of all soils } & & Cropland & 34.1 & 2.04 & 24.8 & 5.92 \\
\hline & & Grassland & 31.2 & 2.63 & 24.7 & 6.15 \\
\hline
\end{tabular}




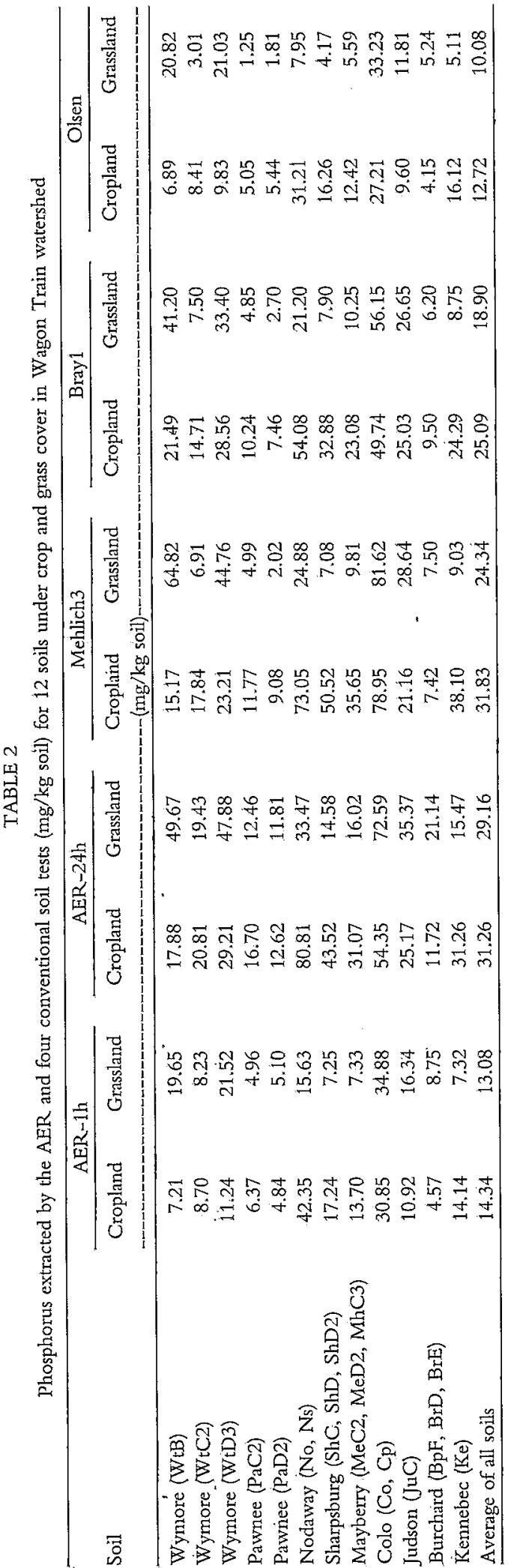

Stream-water samples were filtered by using a glass syringe equipped with Whatman $25-\mathrm{mm}$ GD/X disposable nylon filter media $(0.45 \mu \mathrm{m}$ pore size). In the filtrate, $\mathrm{pH}$ was measured with a combination glass electrode and digital $\mathrm{pH} /$ ion meter (USDA/NRCS, 1996), and P concentration was determined by the modified phosphomolybdate/ascorbic acid method (Olsen and Sommers, 1982).

\section{NRCS Technique}

The NRCS technique (Elrashidi et al., 2003), applies the AER method and runoff model to estimate runoff $P$ for agricultural watersheds, which can be outlined as follows (1) the AER method is used to determine phosphorus release characteristics (PRC) for soils, (2) the runoff model is applied to estimate runoff from soil by an annual rainfall, and (3) an energy conversion factor that relates soil:water suspension (AER method) to rainfall energy is used to estimate runoff $P$.

\section{Phosphorus Release Characteristics}

Implementing the linear relationship between $\mathrm{P}$ released from soil by AER $(\mathrm{mg} / \mathrm{kg}$ soil) and the logarithm of extraction period (hour), two equations are developed to describe PRC for a soil. For the 1- to 48-hour extraction region, the regression equation could be written as follows.

$$
\mathrm{P}=\mathrm{I}+\mathrm{S} 2 \times \log \mathrm{h}
$$

where $\mathrm{P}=\mathrm{P}$ released $(\mathrm{mg} / \mathrm{kg}$ soil), $\mathrm{I}=$ intercept (mg P/kg soil), $\mathrm{S} 2=$ slope, and $\mathrm{h}=$ extraction period in hours.

For the 1- to 60-minute extraction region, the regression equation is written as follows:

$$
\mathrm{P}=\mathrm{I}+(\mathrm{I} \div 1.78) \times \log \mathrm{h}
$$

where $(I \div 1.78)=$ slope $(S 1)$.

In our study, the AER method was applied to estimate the PRC for the 12 soils investigated. Parameters for the linear regression equations (1 and 2) developed to describe $P$ released for the 1- to 60 -minute and 1 - to 48 hour extraction region are given in Table 3.

\section{Estimation of Runoff Water}

The Soil Conservation. Service (USDA/ SCS, 1991) developed the runoff equation to 
TABLE 3

Linear regression equations* used to predict $\mathrm{P}$ released by AER (mg/kg soil) for the 1 to 60 -minute and 1 to 48 hour extraction region as well as the AER-1h-P and AER-24h-P (kg/ha) for 12 soils under crop and grass in Wagon Train watershed

\begin{tabular}{|c|c|c|c|c|c|c|}
\hline \multirow{2}{*}{ Soil } & Iand use & Intercept (I) & \multirow{2}{*}{$\begin{array}{l}\text { Slope (S1) } \\
\text { (mg P/min) }\end{array}$} & \multirow{2}{*}{$\begin{array}{l}\text { Slope (S2) } \\
(\mathrm{mg} \mathrm{P} / \mathrm{h})\end{array}$} & \multirow{2}{*}{$\begin{array}{c}\text { AER-1h-P } \\
(\mathrm{kg} / \mathrm{ha})^{\dagger}\end{array}$} & \multirow{2}{*}{$\begin{array}{c}\text { AER-24h-P } \\
\quad(\mathrm{kg} / \mathrm{ha})^{\dagger}\end{array}$} \\
\hline & \multicolumn{2}{|c|}{$(\mathrm{mg} \mathrm{P} / \mathrm{kg})$} & & & & \\
\hline$W_{\text {ymore }}-\mathrm{W} \mathrm{tB}$ & Cropland & 7.21 & 4.05 & 7.73 & 27.69 & 68.66 \\
\hline Wymore-W/B & Grassland & 19.65 & 11.05 & 21.75 & 75.46 & 190.73 \\
\hline Wymore-WtC2 & Cropland & 8.7 & 4.89 & 8.77 & 33.41 & 79.91 \\
\hline Wymore-WtC2 & Grassland & 8.23 & 4.63 & 8.11 & 31.60 & 74.61 \\
\hline Wymore-WtD3 & Cropland & 11.24 & 6.32 & 13.02 & 43.16 & 1.12 .17 \\
\hline Wymore-WtD3 & Grassland & 21.52 & 12.1 & 19.1 & 82.64 & 183.86 \\
\hline Pawnee-PaC2 & Cropland & 6.37 & 3.58 & 7.48 & 24.46 & 64.13 \\
\hline Pawnee- $\mathrm{PaC} 2$ & Grassland & 4.96 & 2.79 & 5.43 & 19.05 & 47.85 \\
\hline Pawnee-PaD2 & Cropland & 4.84 & 2.72 & 5.64 & 18.59 & 48.46 \\
\hline Pawnee-PaD2 & Grassland & 5.1 & 2,87 & 4.86 & 19.58 & 45.35 \\
\hline Nodaway (No, Ns) & Cropland & 42.35 & 23.82 & 27.87 & 162.62 & 310.31 \\
\hline Nodaway (No, Ns) & Grassland & 15.63 & 8.79 & 12.93 & 60.02 & 128.52 \\
\hline $\begin{array}{l}\text { Sharpsburg } \\
\text { (ShC, ShD, ShD2) }\end{array}$ & Cropland & 17.24 & 9.7 & 19.04 & 66.20 & 167.12 \\
\hline $\begin{array}{l}\text { Sharpsburg } \\
(\mathrm{ShC}, \mathrm{ShD}, \mathrm{ShD} 2)\end{array}$ & Grassland & 7.25 & 4.08 & 5.31 & 27.84 & 55.99 \\
\hline $\begin{array}{l}\text { Mayberry } \\
\text { (MeC2, MeD2, MhC3) }\end{array}$ & Cropland & 13.7 & 7.7 & 12.59 & 52.61 & 119.31 \\
\hline $\begin{array}{l}\text { Mayberry } \\
\quad(\mathrm{MeC} 2, \mathrm{MeD} 2, \mathrm{MhC} 3)\end{array}$ & Grassland & 7.33 & 4.12 & 6.3 & 28.15 & 61.52 \\
\hline Colo $(\mathrm{Co}, \mathrm{Cp})$ & Cropland & 30.85 & 17.35 & 17.03 & 118.46 & 208.70 \\
\hline Colo (Co, Cp) & Grassland & 34.88 & 19.62 & 27.32 & 133.94 & 278.75 \\
\hline Judson-JuC & Cropland & 10.92 & 6.14 & 10.32 & 41.93 & 96.65 \\
\hline Judson-JuC & Grassland & 16.34 & 9.19 & 13.79 & 62.75 & 135.82 \\
\hline $\begin{array}{l}\text { Burchard } \\
\text { (BpF, BrD, BrE) }\end{array}$ & Cropland & 4.57 & 2.57 & 5.18 & 17.55 & 45.00 \\
\hline $\begin{array}{l}\text { Burchard } \\
\text { (BpF, BrD, BrE) }\end{array}$ & Grassland & ' 8.75 & 4.92 & 8.98 & 33.60 & 81.18 \\
\hline Kennebec-Ke & Cropland & 14.14 & 7.95 & 12.4 & 54.30 & 120.04 \\
\hline Kennebec-Ke & Grassland & 7.32 & 4,12 & 5.9 & 28.11 & 59.40 \\
\hline
\end{tabular}

$* \mathrm{P}=\mathrm{I}+\mathrm{S} 1 \times(\log \mathrm{h})$ for 1 to 60 minutes; $\mathrm{P}=\mathrm{I}+\mathrm{S} 2 \times(\log \mathrm{h})$ for 1 to 48 -hour extraction region; where $\mathrm{P}=\mathrm{P}$ released, $I=$ intercept, $S 1$ and $S 2$ is slope, and $h=$ extraction period (hour).

The AER-extractable $\mathrm{P}$ is calculated for the top 0 to $30 \mathrm{~cm}$ soil in hectare. Correlation coefficient $(r)$ between $\mathrm{P}$ and $\log \mathrm{h}$ for all regression equations were $>0.99$.

estimate runoff water from small watersheds by rainfall. The runoff equation is

$$
\begin{aligned}
\mathrm{Q}=\mathrm{R} & -[(200-2 \mathrm{CN}) / \mathrm{CN}]^{2} \\
& \div R+[(800-8 \mathrm{CN}) / \mathrm{CN}]
\end{aligned}
$$

where $Q=$ runoff (inches), $R=$ effective rainfall (inches), and $\mathrm{CN}=$ curve number which is dependent on both the hydrologic soil group and type of land cover (i.e., fallow, crop, or grass).

The annual rainfall for WT watershed (Lancaster County, NE) was taken from the U.S. National Water and Climate Center (NWCC, 2003). In Eq. (3), the effective rainfall ( $R$ ) is the portion of annual rainfall that could generate runoff and it was assumed to be $20 \%$ of the annual rainfall (Elrashidi et al., 2003; Gilbert et al., 1987). The hydrologic group for soil and related $\mathrm{CN}$ numbers for various types of land cover are published in NRCS National Engineering Field Manual (USDA/SCS, 1991).

For agricultural land in the watershed, the effective rainfall ( $R$ ) and the runoff curve numbers were determined then the runoff equation was applied to estimate the runoff water (Q) for soil under fallow, crop, and grass. The equation calculated runoff water in inches. Values were converted to millimeters for this study. 


\section{Estimation of Runoff $P$}

Various forms of $P$ such as moisture are held by soil particles at different energy levels. Kinetic energy exerted by raindrops on surface soil plays a major role in releasing $P$. The Soil Survey Laboratory developed the AER method to determine PRC for soils (Elrashidi et al., 2003). In this method, different levels of energy are applied by water on soil particles when soil suspension is shaken for various periods of time at a constant speed. Understanding the relationship between shaking and rainfall energy enabled the prediction of $P$ released from surface soil by rainfall of known intensity and duration.

Assuming a rainfall intensity of $50 \mathrm{~mm} / \mathrm{h}$ and that rain force affects the top $10-\mathrm{mm}$ layer of soil, a conversion factor (shaking energy/rainfall energy) $=15$ was calculated (Elrashidi et al, 2003). Under the experimental conditions, an energy applied by four minutes of shaking the soil suspension was equivalent to an hour of rainfall event of an intensity of $50 \mathrm{~mm} / \mathrm{h}$.

In this study, we used the conversion factor of 15 to calculate the shaking period (hour) equivalent to the annual rainfall. The log of the calculated shaking period was applied in the respective regression equation ( 1 or 2 ) (Table 3 ) to estimate the amount of $\mathrm{P}$ released from soil by the annual rainfall $(\mathrm{mg} / \mathrm{kg}$-soil). The values of annual rainfall $(\mathrm{mm})$, runoff water $(\mathrm{mm})$, and the amount of $\mathrm{P}$ released ( $\mathrm{mg} / \mathrm{kg}$ soil) were used to estimate the portion of released $\mathrm{P}$ that was removed from surface soil by runoff 'water (runoff-P). With the knowledge of the soil bulk density and assumption that $\mathrm{P}$ was released from the top $10-\mathrm{mm}$ of soil by the annual rainfall, $\mathrm{P}$ removed annually by runoff from a known area (i.e., hectare) could be estimated.

\section{Observed Inflow for WT Reservoir}

In 1962, the dam on a tributary of Salt Creek and construction of the Wagon Train . reservoir were completed. However, the United States Geological Survey (USGS, 2001) has monitored the water flow in Salt Creek and streams in the Platte River basin long before the construction of WT reservoir. The Salt Creek gauge at Roca (USGS gauge \# 06803000, hydrologic unit 10200203, Lancaster County, NE) with a period of record from 1951 to 2000 provided an average monthly water flow rate values for a drainage area of 43,286 hectares (106,880 acres) encompassing WT watershed (USGS, 2001). Recently, the Lower Platte
South Natural Resources District (LPSNRD, 2004) used the ratio of the watershed to the Salt Creek drainage area $(9.34 \%)$ to calculate the average monthly water flow rate values for WT watershed. In this study, we used these average monthly water flow rate values to calculate the observed inflow for WT reservoir.

\section{Geographical Infornation Systems Digital Mapping}

Digital maps for water and $\mathrm{P}$ losses from agricultural land in Wagon Train watershed, Lancaster County, Nebraska, were generated by Geographical Information Systems (GIS) software. The GIS software used was ArcView 8.3 (ESRI, 2003). The input required to generate the map included spatial data layers (soil series and land cover) and the tabular data from both the runoff model and AER method (water and P loss from soils and concentration in runoff water).

The principal spatial data layer used was the Soil Survey Geographic Database (SSURGO) (USDA/NRCS, 1999). Both the National Land Cover (NLCD, 1992) and National Agricultural Statistics Service (NASS, 2003) spatial layers were used to identify areas of cropland and grassland within the county. Other types of land cover, such as urban, forest, water, or marsh were not mapped for the watershed. The proposed technique calculated water and $P$. losses and $\mathrm{P}$ concentration in runoff water for soils under different types of land cover (fallow, crop, and grass). Thus, GIS mapping of agricultural land in the county included data layers for soils and land cover as well as water or P.

\section{RESULTS AND DISCUSSION}

\section{Runoff Water}

The predicted loss of surface water by runoff $\left(\mathrm{m}^{3} /\right.$ ha per year) for 12 soils under different land covers in WT watershed is given in Table 4. Fallow (till without planting) was rarely found in the watershed. However, it was included to provide a worst-case scenario if heavy storms and runoff events have occurred during crop field preparations or early growth stages for the summer crop (April to June). Accordingly, the area of cropped soils (70\% of the watershed) was also used to predict the runoff water for fallow. Grass covered the remainder of the watershed.

Generally, the loss of water by runoff was slightly higher for fallow than cropland while grassland produced relatively lower values. The predicted average (area-weighted) of runoff water was 1242,1122 , and $939 \mathrm{~m}^{3}$ /ha per year 
TABLE 4

Predicted loss of surface water by runoff* expressed as $\left(\mathrm{m}^{3} / \mathrm{ha} / \mathrm{y}\right)$ and $\left(1000 \mathrm{~m}^{3} /\right.$ soil/y) for 12 soils under different land covers in Wagon Train watershed

\begin{tabular}{|c|c|c|c|c|c|c|c|}
\hline \multirow{3}{*}{ Soil (map unit) } & \multirow{3}{*}{ Area (ha) } & \multicolumn{3}{|c|}{ Runoff water* } & \multicolumn{3}{|c|}{ Runoff water* } \\
\hline & & Fallow & Cropland & Grassland & Fallow & Cropland & Grassland \\
\hline & & \multicolumn{3}{|c|}{$\ldots\left(m^{\frac{3}{3}} / h a / y\right)-\cdots$} & \multicolumn{3}{|c|}{$\ldots-\left(1000 \mathrm{~m}^{3} / \mathrm{soil} / \mathrm{y}\right) \cdots$} \\
\hline Wymore (WtB) & 558 & 1280 & 1167 & 1000 & 500 & 456 & 167 \\
\hline Wymore (WtC2) & 1815 & 1280 & 1167 & 1000 & 1626 & 1482 & 544 \\
\hline Wymore (WtD3) & 177 & 1280 & 1167 & 1000 & 158 & 144 & 53 \\
\hline Pawnee (PaC2) & 343 & 1280 & 1167 & 1000 & 307 & 280 & 103 \\
\hline Pawnee (PaD2) & 77 & 1280 & 1167 & 1000 & 69 & 63 & 23 \\
\hline Nodaway (No, Ns) & 203 & 1057 & 901 & 640 & 150 & 128 & 39 \\
\hline Sharpsburg (ShC, ShD, ShD2) & 177 & 1057 & 901 & 640 & 131 & 111 & 34 \\
\hline Mayberry (MeC2, MeD2, MhC3) & 157 & 1280 & 1167 & 1000 & 141 & 128 & 47 \\
\hline Colo (Co, Cp) & 152 & 1195 & 1084 & 880 & 127 & 116 & 40 \\
\hline Judson (JuC) & 101 & 1057 & 901 & 640 & 75 & 64 & 19 \\
\hline Burchard $(\mathrm{BpF}, \mathrm{BrD}, \mathrm{BrE})$ & 81 & 1057 & 901 & 640 & 60 & 51 & 16 \\
\hline Kennebec $(\mathrm{K} t)$ & 45 & 1057 & 901 & 640 & 33 & 28 & 9 \\
\hline Weighted Average & & 1242 & 1122 & 939 & & & \\
\hline Total & 3885 & & & & 3377 & 3051 & 1094 \\
\hline
\end{tabular}

*USDA/SCS, 1991.

for fallow, cropland, and grassland, respectively. These results accounted for 17.0, 15.4, and $12.9 \%$ of the annual rainfall for fallow, cropland, and grassland, respectively. Similar values were reported for 13 United States soils of humid regions (rainfall $>800 \mathrm{~mm} / \mathrm{y}$ ) where the average was $16 \%$ for fallow, $15 \%$ for cropland, and $12 \%$ for grassland (Elrashidi et al., 2003).

However, these values were relatively higher than those reported for Lancaster County, NE where WT watershed is located (Elrashidi et al., 2004). This could be attributed to the slow water infiltration rate (hydrologic group D) for the dominant soils (Wymore, Pawnee, and Mayberry) in the watershed. These three soils occupy approximately $80 \%$ of the agricultural land in the watershed. The map (Fig. 2), illustrating the water loss by runoff, indicates that these soils of poor hydrologic properties and high runoff potential (runoff $>100 \mathrm{~mm} / \mathrm{y}$ ) are evenly distributed throughout the watershed.

Table 4 shows the total volume of water generated from each of the 12 major soils $^{3} /$ soil per year) under different land covers in the watershed. The results indicated that Wymore$\mathrm{WtC} 2$, irrespective of the land cover, produced the highest volume of runoff, mainly because of its abundance in the watershed. Expectedly, Kennebec soil, which had very limited area, generated the least amount of runoff water. The total annual loss of runoff water from the 12 major soils was 4.15 million $\mathrm{m}^{3}$. Under the worst-case scenario, this value should increase
$(8 \%)$ to 4.47 million $\mathrm{m}^{3}$. The area of the $12 \mathrm{ma}-$ jor soils ( $3885 \mathrm{ha}$ ) cover about $96 \%$ of the entire watershed. Thus, when the entire watershed area (4042 ha) was considered the total annual runoff accounted for 4.31 million $\mathrm{m}^{3}$ of water.

Table 5 and Fig. 3 show (1) the observed average monthly inflow for WT reservoir for a 50-year period between 1951 and 2000 (USGS, 2001), (2) the predicted surface water runoff for WT watershed, and (3) the historic monthly rainfall. The historic record of monthly rainfall for Lancaster County (NWCC, 2003) was used to predict the runoff water. The runoff model (USDA/SCS, 1991) appeared to underestimate the observed water flow to the reservoir for February and March while overestimating the inflow for August and September.

According to the historic record of Lancaster County (NWCC, 2003), a total of $607 \mathrm{~mm}$ (23.9 inches) of snow falls during the winter. Usually, a large portion of this snow remains on the ground because of the cold weather. The moderate temperature in early spring could melt much of the snow, which increases the water inflow for the reservoir. This snow melt might explain the underestimation of the inflow for February and March. During the hot summer period, crops such as corn and soybean are in full growth and have a high demand for water. Further, the high temperature and low relative humidity could dry the surface soil and increase evapotranspiration by plants. These combined factors could reduce the runoff and reservoir inflow 
and thus explain the overestimation for August and September. The underestimation 'in early spring appeared to offset the summer's overestimation and kept the predicted annual runoff water $\left(4.31\right.$ million $\left.\mathrm{m}^{3}\right)$ in good agreement with the observed annual inflow $\left(4.25\right.$ million $\left.\mathrm{m}^{3}\right)$ :

\section{Phosphorus Released by Rainfall}

Linear regression equations to predict $\mathrm{P}$ released by the AER technique for the 12 soils under different land covers are given in Table 3. The equations included both the 1 - to 60 minute and 1- to 48 -hour extraction regions which were used to predict $P$ released from soils (mg/kg soil) by annial rainfall. The intercept at 1-hour extraction period reflects mainly the water soluble and adsorbed P for soil (Elrashidi et al., 2003). For the 12 soils, 'it varied widely between 4.57 and $42.4 \mathrm{mg} / \mathrm{kg}$ soil for cropland and from 4.96 to $34.9 \mathrm{mg} / \mathrm{kg}$ soil for grassland.

With the exception of Nodaway and Colo soils, the data in general indicated a low $\mathrm{P}$ concentration. The 24-hour extractable $\mathrm{P}$ was ranging between 11.7 and $80.8 \mathrm{mg} / \mathrm{kg}$ soil for cropland and from 11.8 to $72.6 \mathrm{mg} / \mathrm{kg}$ soil for grassland. No trend was observed for the effect of land cover on either 1-hour or 24-hour AER-extractable P. For 24 U.S. soils, the AERh1-P ranged between 3.8 and $136 \mathrm{mg} / \mathrm{kg}$ soil and from 14.8 to $256 \mathrm{mg} / \mathrm{kg}$ soil for the AER24h-P (Elrashidi et al., 2003). The authors suggested that the high $\mathrm{P}$ values were probably

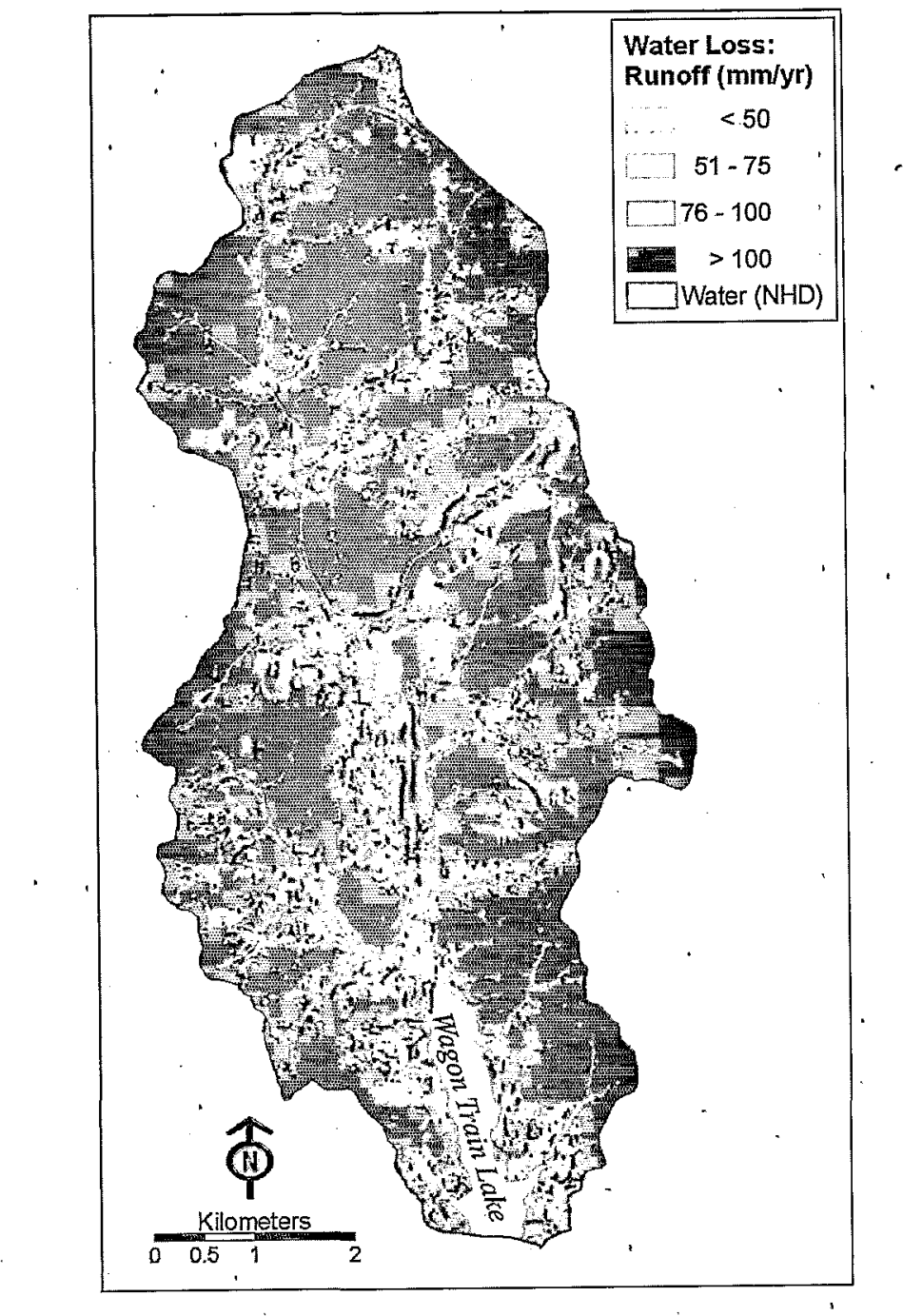

Fig. 2. Water loss by runoff for soils $(\mathrm{mm} / \mathrm{y})$ in Wagon Train watershed, Lancaster County, Nebraska. 
TABLE 5

Average monthly rainfall $(\mathrm{mm})$, observed inflow* $\left(\mathrm{m}^{3}\right)$ for Wagon Train (WT) reservoir, and predicted surface water runoff ${ }^{\dagger}$ for $W T$ watershed

\begin{tabular}{lcrr}
\hline Month & $\begin{array}{c}\text { Rainfall } \\
(\mathrm{mm})\end{array}$ & $\begin{array}{c}\text { Observed } \\
\text { Inflow* }\left(\mathrm{m}^{3}\right)\end{array}$ & \multicolumn{1}{c}{$\begin{array}{c}\text { Predicted } \\
\text { runoff }^{+}\left(\mathrm{m}^{3}\right)\end{array}$} \\
\hline January & 15 & 133,860 & 91,704 \\
February & 18 & 244,371 & 108,241 \\
March & 55 & 610,517 & 327,729 \\
April & 75 & 475,674 & 446,493 \\
May & 99 & 653,013 & 583,297 \\
June & 102 & 620,296 & 602,841 \\
July & 78 & 574,396 & 461,526 \\
August & 89 & 221,684 & 524,667 \\
September & 86 & 161,071 & 508,130 \\
October & 55 & 289,677 & 323,219 \\
November & 35 & 146,678 & 205,958 \\
December & 23 & 117,571 & 135,301 \\
Year & 729 & $4,248,808$ & $4,314,713$ \\
\hline
\end{tabular}

*USGS, 2001.

†USDA/SCS, 1991.

associated with soils treated with $\mathrm{P}$ fertilizers or manure.

\section{Available P for Crops}

The AER technique can be used to quantify the readily available $P$ (AER-1h-P) and $P$ supplying power (AER-24h-P) for soils. In their study on 24 U.S. soils, Elrashidi et al. (2003) reported that the AER-1h-P was mainly driven from water soluble and adsorbed forms. The authors also found that the AER-24h could remove all $\mathrm{P}$ forms dissolved by Bray1 and Olsen solution. Olsen and Khaswneh (1980) reported that the resin-extractable $\mathrm{P}$ is related to labile $\mathrm{P}$ and to Olsen's bicarbonate extraction. Therefore, the AER-24h could be considered a valid measure of the capacity factor for soils. Table 2 shows the amount of $\mathrm{P}$ extracted $(\mathrm{mg} / \mathrm{kg}$ soil) by both the AER-1h and AER-24h as well as three conventional soil tests (Olsen, Bray1, and Mehlich3) for 12 soils under crop and grass in WT watershed.

The amount of $P$ extracted by the AER-1h and Olsen test was very similar, and a highly significant correlation $(r=0.98)$ was obtained between the two methods for soils under crop and grass. Both Bray1 and Mehlich3 extracted relatively higher amount of $P$ than the AER -1 h. For Bray1, a highly significant correlation with the AER-1h was obtained for soils under crop $(r=0.95)$ and grass $(r=0.98)$. For Mehlich3, the corresponding correlation with the AER-1h was 0.94 and 0.99 for soils under crop and grass, respectively.

The AER-24h extracted more $\mathrm{P}$ than Olsen test but similar to that removed by either Bray1 or Mehlich3 test. Like the AER-1h, a highly significant correlation was also found between the AER-24h and each of the three soil tests (Olsen, Bray1, and Mehlich3) for soils under crop and grass.

Both the AER-1h-P, and AER-24h-P were calculated as $\mathrm{kg} / \mathrm{ha}$ for the 0 - to $30-\mathrm{cm}$ root zone (Table 3). Most cropped soils had a readily available $\mathrm{P}$ below $100 \mathrm{~kg} / \mathrm{ha}$, indicating a need for $\mathrm{P}$ addition to sustain commercial crops such as corn or soybeans. Grass P requirements are known to be much lower than crops. However, even with the relatively low $\mathrm{P}$ concentrations found for most soils under grass, some grassland soils might need $\mathrm{P}$ fertilizers. On the other hand, the AER-24h-P ranged between 45 and 310 $\mathrm{kg} / \mathrm{ha}$, with an average of $120 \mathrm{~kg} / \mathrm{ha}$ for cropped

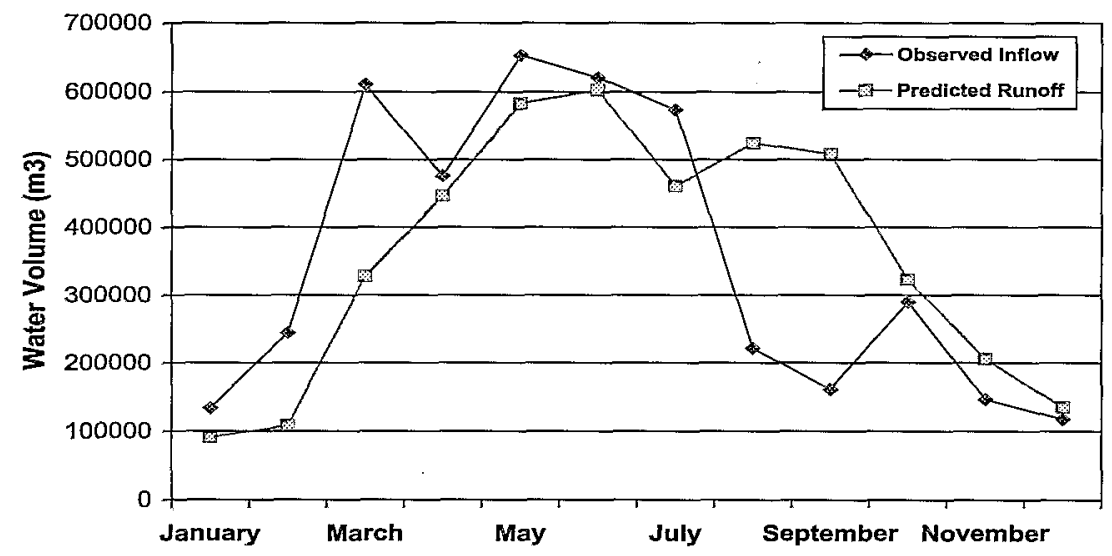

Fig. 3. Observed average monthly water inflow for Wagon Train (WT) reservoir $\left(\mathrm{m}^{3}\right)$, and predicted surface water runoff for WT watershed $\left(\mathrm{m}^{3}\right)$. 
soils. For soils under grass, the range was 45 to $278 \mathrm{~kg} / \mathrm{ha}$, with an average of $112 \mathrm{~kg} / \mathrm{ha}$. It is unlikely that all $\mathrm{P}$ forms extracted by the AER$24 \mathrm{~h}$ would be available for plant roots during an annual growth season. Accordingly, these data suggested a relatively low $\mathrm{P}$ capacity since most soils were below $150 \mathrm{~kg} / \mathrm{ha}$.

\section{Runoff $P$}

Land cover (i.e., crop, grass, etc.) could affect the amount of $\mathrm{P}$ released from surface soil by rainfall in two different ways: (1) it reduces the volume of surface water runoff generated by rainfall, and (2) it minimizes the area of surface soil exposed to direct rainfall energy. The results (Table 4) indicate that the average runoff water generated by annual rainfall was $1242 \mathrm{~m}^{3} /$ ha for bare soils (fallow), which was higher than that of either cropland $\left(1122 \mathrm{~m}^{3} / \mathrm{ha}\right)$ or grassland $(939$ $\mathrm{m}^{3} / \mathrm{ha}$ ). The reducing effect on surface water runoff was also observed for crop residue. Gilley et al. (1986a, 1986b) used a rainfall simulator to measure runoff from plots on which corn, sorghum, and soybean residues were added at rates ranging from 0 to $13.5 \mathrm{t} / \mathrm{ha}$. The authors found that increased rate of surface cover resulted in reduced runoff.

The effectiveness of vegetation canopy in reducing the energy of rainfall striking the soil surface is dependent on the area covered by can- opy. For permanent pasture or grass, the canopy covers an area relatively constant during the entire year in comparison' to the wide range of coverage for most agronomic crops. It is difficult to estimate the magnitude of reduction in runoff $\mathrm{P}$ caused by different types of land cover. However, in comparison to cropland and grassland, fallow (bare soil) releases a higher amount of $\mathrm{P}$ in runoff water and represents the worstcase scenario.

The results in Table 6 indicate that the average annual runoff $P$ was $243 \mathrm{~g} / \mathrm{ha}$ for fallow, $217 \mathrm{~g} / \mathrm{ha}$ for cropland, and $190 \mathrm{~g} / \mathrm{ha}$ for grassland in the watershed. These values are on the low side but still within the range for 24 U.S. soils where the estimated average ranged between 0.09 and 8.3 (fallow), 0.06 and 7.5 (cropland), and 0.01 and $6.0 \mathrm{~kg} \mathrm{P} /$ ha per year for grassland (Elrashidi et al., 2003). The authors reported that the high runoff $\mathrm{P}$ values were probably associated with soils treated with $\mathrm{P}$ fertilizer or manure. In a field experiment on an Iowa soil (fallow), Tabbara (2003) studied P loss to runoff water from a 90-minute rainfall event after application of manure or fertilizer. $\mathrm{He}$ found that the mean loss of dissolved $\mathrm{P}$ by runoff water ranged from 0.38 to $1.76 \mathrm{~kg} / \mathrm{ha}$.

No large livestock feedlots or intensive cattle grazing are currently present in WT watershed area. Phosphorus fertilizer (50 to 60

\section{TABLE 6}

Predicted P loss from soils by runoff expressed as $(\mathrm{g} / \mathrm{ha} / \mathrm{y})$ and $(\mathrm{kg} /$ soil $/ \mathrm{y})$ as well as $\mathrm{P}$ concentration in runoff water $(\mu \mathrm{g} / \mathrm{L})$ generated from 12 soils under different land covers for Wagon Train watershed

\begin{tabular}{|c|c|c|c|c|c|c|c|c|c|}
\hline \multirow{3}{*}{ Soil } & \multicolumn{6}{|c|}{$P$ loss from soils by runoff water } & \multicolumn{3}{|c|}{$P$ concentration in runoff water } \\
\hline & Fallow & Cropland & Grassland & Fallow & Cropland & Grassland & Fallow & Cropland & Grassland \\
\hline & \multicolumn{3}{|c|}{ - $(\mathrm{g} / \mathrm{ha} / \mathrm{y})$} & \multicolumn{3}{|c|}{ - - - } & \multicolumn{3}{|c|}{$---\infty-\infty(\mu \mathrm{g} / \mathrm{L})-\cdots$} \\
\hline Wymore (WtB) & 161 & 147 & 344 & 63 & 57 & 58 & 126 & 126 & 344 \\
\hline Wymore (WtC2) & 194 & 177 & 144 & 247 & 225 & 78 & 152 & 152 & 144 \\
\hline Wymore (WtD3) & 251 & 229 & 377 & 31 & 28 & 20 & 196 & 196 & 377 \\
\hline Pawnee $\left(\mathrm{P}_{2} \mathrm{C} 2\right)$ & 142 & 130 & 87 & 34 & 31 & 9 & 111 & 111 & 87 \\
\hline Pawnee (PaD2) & 108 & 98 & 89 & 6 & 5 & 2 & 84 & 84 & 89 \\
\hline $\begin{array}{l}\text { Nodaway } \\
\text { (No, Ns) }\end{array}$ & 781 & 665 & 174 & 111 & 94 & 11 & 738 & 738 & 272 \\
\hline $\begin{array}{l}\text { Sharpsburg } \\
\text { (ShC, ShD, ShD }\end{array}$ & $\begin{array}{l}318 \\
D 2)\end{array}$ & 271 & 81 & 39 & 33 & 4 & 301 & 301 & 126 \\
\hline $\begin{array}{l}\text { Mayberry } \\
\qquad(\mathrm{MeC} 2, \mathrm{MeD} 2,1\end{array}$ & $\begin{array}{c}306 \\
\text { MhC3) }\end{array}$ & $.279^{*}$ & 128 & 34 & 31 & 6 & 239 & 239 & 128 \\
\hline Colo (Co, Cp) & 643 & .583 & 533 & 68 & 62 & 24 & 538 & 538 & 605 \\
\hline Judson $(\mathrm{JuC})$ & 201 & 172 & 182 & 14 & 12 & 6 & 190 & 190 & 284 \\
\hline $\begin{array}{l}\text { Burchard } \\
(\mathrm{BpF}, \mathrm{BrD}, \mathrm{BrE})\end{array}$ & ह) 84 & 72 & 97 & 5 & 4 & 2 & 80 & ${ }^{80}$ & 152 \\
\hline Kennebec (Ke) & 261 & 222 & 81 & 8 & 7 & 1 & 247 & 247 & 127 \\
\hline Weighted average & 243 & 217 & 190 & 660 & 591 & 221 & 195 & 194 & 202 \\
\hline
\end{tabular}


$\mathrm{kg} \mathrm{P}_{2} \mathrm{O}_{5} / \mathrm{ha}$ ) is usually applied to cropped soils during the preparation for summer crop, whereas grassland soils receive smaller amounts and less frequent fertilizer application as well as occasional animal-waste additions. The fact that the soil sampling has been completed before fertilizer application might explain the relatively low $\mathrm{P}$ content found particularly for cropped soils and runoff waters. We found that five cropped soils (Wymore-WtB and WymoreWtD3, Colo, Judson, and Burchard) were depleted of $\mathrm{P}$ by the previous year's cropping, with a runoff $\mathrm{P}$ lower than soils under grass. This might appear in contradiction with Sonzogoni et al., (1980) who stated that cropped soils, in general, generate higher $P$ concentration in runoff water than grassland soils.

\section{Phosphorus Loss and Loading}

For the agricultural land in WT watershed, we assumed that most of the P loss from soils by runoff was transported eventually to WT reservoir. Table 6 shows the estimated $P$ loss by runoff for the 12 soils under different land covers in the watershed. As mentioned, we included fallow in this study to estimate the worst-case scenario when all cropland areas could be considered as fallow due to heavy spring storms. Under the worst-case scenario, the annual $P$ loss by runoff from soils would increase by $8.5 \%$ from 812 to $881 \mathrm{~kg}$. As mentioned above (Table 4), the runoff water would increase by $8 \%$ from 4.15 to 4.47 million $\mathrm{m}^{3}$. This change, however, would not have any significant effect on the average $P$ concentration in runoff water generated from the entire watershed area.

Table 6 shows that the predicted $P$ concentration varied widely in runoff water generated from different soils and land covers. For cropped soils, the $\mathrm{P}$ concentration in runoff water ranged from 80 to $738 \mu \mathrm{g} / \mathrm{L}$, with an average of 194 $\mu \mathrm{g} / \mathrm{L}$, whereas it ranged from 87 to $605 \mu \mathrm{g} \mathrm{P} / \mathrm{L}$, with an average of $202 \mu \mathrm{g} \mathrm{P} / \mathrm{L}$ for soils under grass. The predicted area-weighted average $\mathrm{P}$ concentration for the runoff water generated from the entire watershed (cropland and grassland) was $196 \mu \mathrm{g} / \mathrm{L}$.

Phosphorus loss from soils generally occurs from hydrologically active areas of a watershed where surface runoff contributing to stream flow is coincident with areas of high soil $P$ (Gburek and Sharpley, 1998; Gburek et al., 2000). They concluded that $\mathrm{P}$ loss may be most efficiently managed by focusing on controlling soil $P$ levels and fertilizer as well as manure applications in the watershed zones most likely to produce surface runoff. Accordingly, management practices to prevent $P$ loss from agricultural watersheds should focus on defining, targeting, and remediating the critical source areas of $\mathrm{P}$ loss (hot spots).

We applied GIS to present the data in the watershed map (Fig. 4). This approach allowed us to identify the area and location of hot spots as well as soils generating runoff water with high $\mathrm{P}$ concentration. The dark area in the map shows Nodaway, Colo, and Sharpsburg soils, which produced runoff water exceeding $300 \mu \mathrm{g} / \mathrm{L}$.

Soluble $\mathrm{P}$ concentration of at least $20 \mu \mathrm{g} / \mathrm{L}$ in fresh waters can cause eutrophication (USEPA, 1996). To reduce the impact on surface water bodies, USEPA (1986) recommended a limit of $50 \mu \mathrm{g} / \mathrm{L}$ for total $\mathrm{P}$ in streams that enter lakes and $100 \mu \mathrm{g} / \mathrm{L}$ for total $\mathrm{P}$ in flowing water. The data in Table 6 and Fig. 4 indicate that the predicted $P$ concentration in runoff water exceeded the recommended limits and could cause an environmental problem for WT reservoir.

We used the predicted average $\mathrm{P}$ concentration in surface water runoff generated from the entire watershed $(196 \mu \mathrm{g} \mathrm{P} / \mathrm{L})$ and the volume of monthly surface water runoff (Table 5) to estimate the monthly P loading $(\mathrm{kg})$ for WT reservoir, which is illustrated in Fig. 5. Expectedly, the results indicated that $\mathrm{P}$ loading into the reservoir was least during the winter and averaging about $20 \mathrm{~kg} / \mathrm{mo}$. Most of $\mathrm{P}$ loading in the reservoir occurred during the spring and summer $(93 \mathrm{~kg} / \mathrm{mo})$ due to the rainfall pattern. The predicted annual loading for WT reservoir is $846 \mathrm{~kg}$ $\mathrm{P}$, which was generated from the entire area of the watershed (4042 ha).

The LPSNRD (2004) collected monthly surface water samples from five locations in WT reservoir to monitor the concentration of $\mathrm{P}$ and other contaminants. The dissolved $\mathrm{P}$ concentration ranged between 70 and $260 \mu \mathrm{g} / \mathrm{L}$, with an average of $140 \mu \mathrm{g} / \mathrm{L}$. This average was lower than the predicted average $P$ concentration in the surface water runoff of $196 \mu \mathrm{g} / \mathrm{L}$. The difference could be attributed to the high $\mathrm{pH}$ values observed for water in the reservoir. The IPSNRD (2004) reported a $\mathrm{pH}$ value ranging from 7.33 to 9.64 , with an average of 8.49 for the five water samples collected at different locations in the reservoir.

The water $\mathrm{pH}$ values for the 12 cropped soils were mainly within the acidic range fluctuating between 5.56 and 6.58 , with an average of 5.92 (Table 1). Under grass, $\mathrm{pH}$ values ranged 


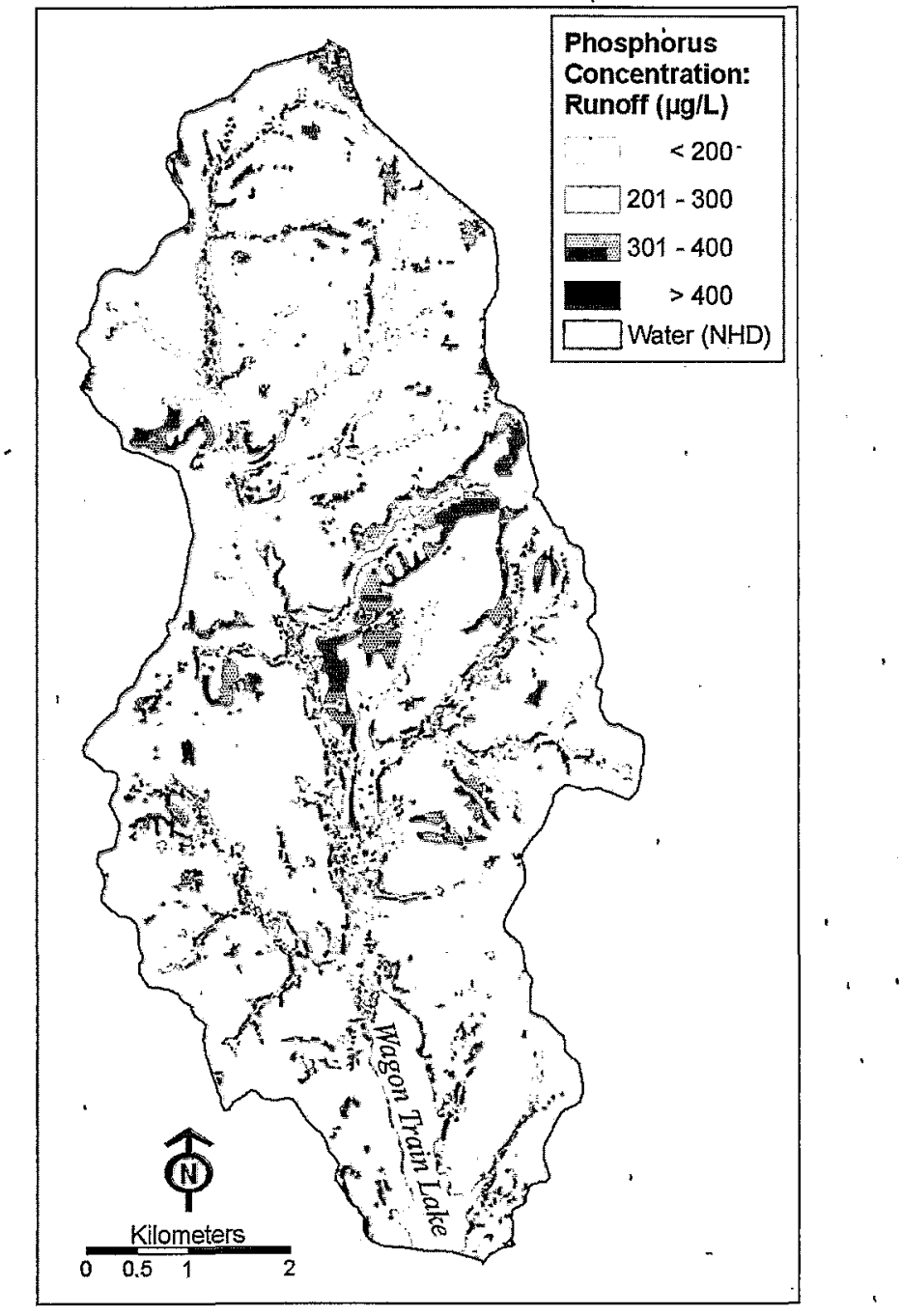

Fig. 4. Phosphorus concentration in runoff water from soils $(\mu \mathrm{g} / \mathrm{L})$ in Wagon Train watershed.

between 5.55 and 7.00 , with an average of 6.15 . Monocalcium phosphate $\left[\mathrm{Ca}\left(\mathrm{H}_{2} \mathrm{PO}_{4}\right)_{2}\right]$ is the major form of phosphate fertilizers usually added to these soils. Changing $\mathrm{pH}$ of the runoff water from acidic and near neutral to the alkaline range in the reservoir could transform the $\mathrm{Ca}\left(\mathrm{H}_{2} \mathrm{PO}_{4}\right)_{2}$ to $\mathrm{CaHPO}_{4}$ or $\mathrm{Ca}_{3}\left(\mathrm{PO}_{4}\right)_{2}$, which both have lower solubility in water (Lindsay, 1979). Further, a presence of large populations of algae, weeds, and aquatic plants in the reservoir could assimilate $\mathrm{P}$ and decrease the concentration in water.

Most of the runoff from agricultural land in WT watershed is expected during the spring, summer, and early fall (Fig. 3). Phosphorus concentration from major streams at the beginning of spring (March), ranged from $99 \mu \mathrm{g} / \mathrm{L}$ to 240 $\mu \mathrm{g} / \mathrm{L}$, with an average of $162 \mu \mathrm{g} / \mathrm{L}$ (S.D. $=40$ $\mu \mathrm{g} / \mathrm{L}$ ). The predicted value of $196 \mu \mathrm{g} P / \mathrm{L}$ is greater than and is within 1 S.D. of the observed average $P$ concentration in streams. Meanwhile, the $\mathrm{pH}$ value in stream water samples ranged from 8.10 to 8.57 , with an average of 8.39 . This $\mathrm{pH}$,was higher than the average $\mathrm{pH}$ value (about 6.00) measured in soils (Table 1). The technique used in this study predicted $\mathrm{P}$ concentration in runoff at the edge of field. The increase in water $\mathrm{pH}$ as well as $\mathrm{P}$ removal by aquatic weeds and algae could be the cause of the lower P concentration observed in stream water.

Furthermore, the average $\mathrm{P}$ concentration observed in the main stream samples for the 


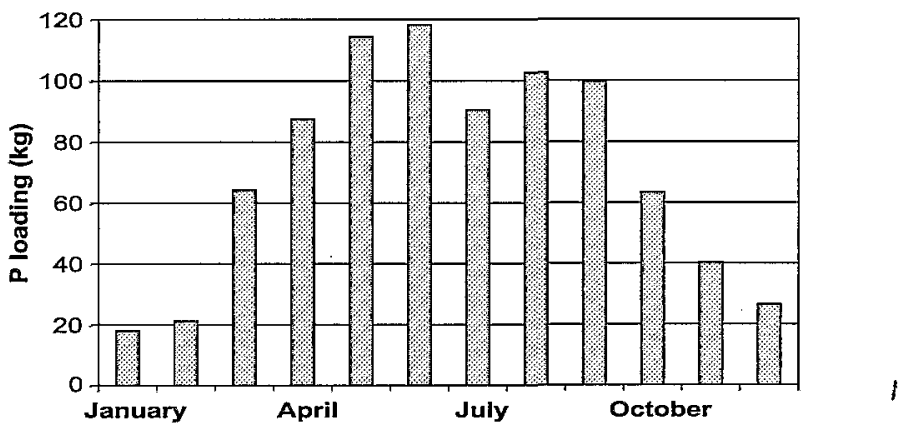

Fig. 5. Predicted average monthly phosphorus loading by runoff water $(\mathrm{kg})$ in Wagon Train reservoir.

entire rainy season (March through October) ranged between $157 \mu \mathrm{g} / \mathrm{L}$ (March) and $346 \mu \mathrm{g} / \mathrm{L}$ (July), with an average of $252 \mu \mathrm{g} / \mathrm{L}$ (S.D. $=65$ $\mu \mathrm{g} / \mathrm{L}$ ) (Fig. 6). This average rainy season $\mathrm{P}$ concentration is greater than the predicted $\mathrm{P}$ concentration of $196 \mu \mathrm{g} / \mathrm{L}$. Field applications of $\mathrm{P}$ fertilizer (April and May) for the summer crops could contribute to the relatively higher observed $P$ concentration (May through August) in water. However, the predicted $P$ value is within one standard deviation of the observed stream $\mathrm{P}$ concentration for the entire rainy season.

In conclusion, we need to emphasize that the predicted $\mathrm{P}$ value was calculated for runoff water generated at field sites and not in WT streams or reservoir. Factors affecting $\mathrm{P}$ concentration in runoff water after leaving field sites such as change in water chemistry as well as $\mathrm{P}$ removal by aquatic weeds and algae should be taken into consideration. The data suggested that the two factors have lowered $\mathrm{P}$ concentration by approximately $17 \%$ (from 196 to 162 $\mu \mathrm{g} / \mathrm{L}$ ). Therefore, when we consider factors affecting $P$ concentration in runoff after leaving field sites, the technique could provide a reasonable estimation of $\mathrm{P}$ concentration in stream water.
In this study, soil samples were collected before fertilizer application to reflect background soils condition. This also explains the low $\mathrm{P}$ content found in soils. However, future study should include sampling from fertilized soils to predict the worst-case scenario for P loss by runoff.

\section{CONCLUSIONS}

Agricultural chemicals such as phosphorus and nitrogen can be transported from surface soils by runoff to freshwater bodies. Therefore, agricultural watersheds, particularly in high rainfall areas, may pose risk to the water quality in streams, rivers, and lakes. The NRCS technique uses existing climatic, hydrologic, and soil survey databases to estimate the loss of water and $P$ by runoff from agricultural watersheds. It can be applied on a small watershed (20 to $40 \mathrm{ha}$ ) or a large area of agricultural land that may include thousands of hectares. The GIS software, which uses available spatial soil and land cover layers as well as the predicted data for water and P losses, can be applied to develop digital maps. These maps improve data presentation and communications with the clientele as well as identify $\mathrm{P}$ hot spots within a watershed.

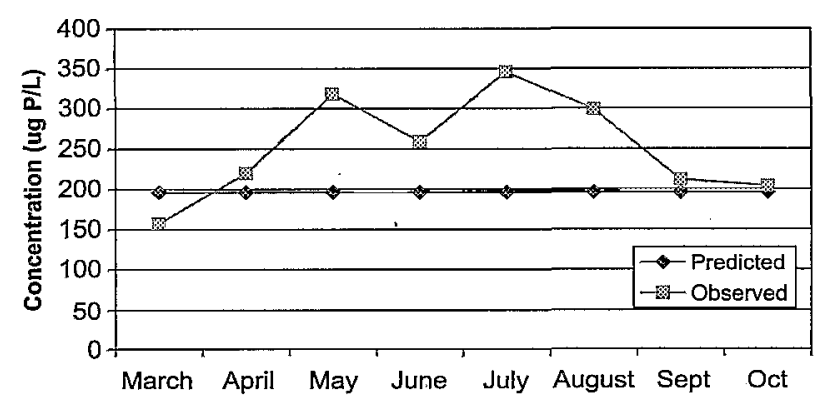

Fig. 6. Predicted and observed average monthly phosphorus concentration ( $\mu \mathrm{g} / \mathrm{L}$ ) in Wagon Train watershed stream water. 
The technique predicted annual runoff water of 4.31 million $\mathrm{m}^{3}$, with an average $\mathrm{P}$ concentration of $196 \mu \mathrm{g} / \mathrm{L}$ for WT watershed. The predicted and observed values for the runoff and $\mathbf{P}$ loss appeared to have reasonable agreement, particularly when factors affecting $\mathrm{P}$ concentration in streams are considered. The technique offers a cost-effective, quick, and reliable tool to conduct exploratory evaluation for large area of agricultural watershed. Thus, lengthy and site-specific studies could be focused on certain areas of high risk.

Even in the absence of potential sources of $\mathrm{P}$ contamination such as animal feedlot, intensive cattle grazing, heavy $\mathrm{P}$ fertilization or $\mathrm{P}$ enriched soil minerals, the agricultural land in WT watershed still can release enough $P$ in runoff to cause eutrophication of fresh waters. Compliance with the recommended P limits for confined and flowing water systems appears to be a formidable task. Management practices or nutrient attenuation mechanisms (i.e., riparian wetland) that can reduce $P$ concentration in runoff waters before discharging into freshwater bodies should be considered. To be most effective, $\mathrm{P}$ management efforts should be targeted to identified hot spot areas within a watershed that are most vulnerable to P loss.

\section{ACKNOWLEDGMENTS}

The authors would like to acknowledge the input from many individuals at the National Soil Survey Center (NSSC). We are especially grateful to Robert J. Ahrens, NSSC Director, for his support during the course of this study. We also appreciate the invaluable suggestions and constructive criticism from Robert Grossman, Warren Lynn, Tom Reedy, and Lyle Steffen. The authors also thank members of the Soil Survey Laboratory: Patty Jones, Chris Lee, Tom Zimmer, Jan Lang, and Pam VanNeste for soil and water analysis.

\section{REFERENCES}

Bray, R. H., and L. T. Kurtz. 1945. Determination of total, organic, and available forms of phosphorus in soils. Soil Scì. 59:39-45.

Brown, L. E., L. Quandt, S. Scheinost, J. Wilson, D. Witte, and S. Hartung. 1980. Soil Survey of Lancaster County, Nebraska. U.S. Dept. of Agriculture, Soil Conservătion Service. 1-174.

Carpenter; S. R., N. F. Caraco, D. L. Correl, R. W. Howarth, A. N. Sharpley, and V. H. Smith. 1998.
Nonpoint pollution of surface waters with phosphorus and nitrogen. Ecol. Appl. 8:559-568.

Elrashidi, M. A., A. K. Alva, Y. F. Huang, D. V. Calvert, T. A. Obreza, and Z. L. He. 2001. Accumulation and downward transport of phosphorus in Florida soils and relationship to water quality. Commun. Soil Sci. Plant Anal. 32: 3099-3119.

Elrashidi, M. A., M. D. Mays, and P. E. Jones. 2003. A technique to estimate release characteristics and runoff phosphorus for agricultural land. Commun. Soil Sci. Plant Anal. 34:1759-1790.

Elrashidi, M. A., M. D. Mays, S. D. Peaslee, and D. G. Hooper. 2004. A technique to estimate nitrate- $\mathrm{N}$ loss by runoff and leaching for agricultural land: Lancaster County, Nebraska. Commun. Soil Sci. Plant Anal., Volume: 35, Issues: 17/18 (in press).

ESRI. 2003. Environmental Systems Research Institute, ArcGIS Version 8.3 [Online]. Available at http://www.esri.com.

Gburek, W. J., and A. N. Sharpley. 1998. Hydrologic controls on phosphorus loss from upland agricultural watersheds. J. Environ. Q̄ual. 27:267-277.

Gburek, W. J., and A. N. Sharpley, L. Heathwaite, and G. J.' Folmar. 2000. Phosphorus management at the watershed scale: A modification of the phosphorus index. J. Environ. Qual. 29:130-144.

Gilbert, W. A., D. J. Graczyk, and W. R. Krug. 1987. Average annual runoff in the United States, 1951-1980. Hydrologic' investigations. National Atlas HA-710, U.S. Geological Survey, Reston, VA.

Gilley, J. E.,.S. C. Finkner, R. G. Spomer, and L. N. Mielke. 1986a. Runoff and erosion as affected by corn residue: Part I. Total losses. ASAE. 29: $157-160$.

Gilley, J. E., S. C. Finkner, and G. E. Varvel. 1986b. Runoff and erosion as affected by sorghum and soybean residue. ASAE. 29:1605-1610.

Lemunyon, J. I., and R. G. Gilbert. 1993. The concept and need for a phosphorus assessment tool. J. Prod. Agric. 6:483-486.

Lindsay, W. L. 1979. Chemical equilibria in soils. John Wiley \& Sons, New York.

LPSNRD. 2004. Lower Platte South Natural Resources District. A community-based watershed management plan for Wagon Train lake, Lancaster County, Nebraska. Nebraska Department of Environmental Quality, Linçoln, NE.

Mehlich, A. 1984. Mehlich 3 soil test extractant: a modification of Mehlich 2 extractant. Commun. Soil Sci. Plant Anal. 15:1409-141.

NASS. 2003. National Agricultural Statistics Service [Online]. Available at http://wwww.nass.usda.gov/ ne. USDA, NASS, Washington, DC.

NLCD. 1992. National Land .Cover Data for Nebraska. Version 05-07-00 nominal Thematic Mapper [Online]. Available at http://landcover.usgs. gov/natllandcover.html. USGS, Washington, DC. 
Novak, J. M., D. W. Watts, P. G. Hunt, and K. C. Stone. 2000. Phosphorus movement through a coastal plain soil after a decade of intensive swine manure application. J. Environ. Qual. 29:13101315.

NWCC. 2003. U.S. National Water and Climate Center. [Online]. Available at http://www. . WCC.NRCS.gov/water/W_CLIM.html. USDA, Washîngton, DC.

Olsen, S. R, and F. E. Khasawneh. 1980. Use and limitations of physical-chemical criteria for assessing the status of phosphorus in soils P. 361-410. In: F. E. Khasawneh et al (ed.). The Role of Phosphorus in Agriculture. ASA and SSSA, Madison, WI.

Olsen, S. R., and L. E. Sommers. 1982. Phosphorus. P. 403-430. In: A. L. Page et al (ed.). Methods of soil analysis. Part 2. 2nd ed. ASA and SSSA, Madison, WI.

Olsen, S. R., C. V. Watanabe, and L. A. Dean. 1954. Estimation of available phosphorus in soils by extraction with sodium bicarbonate. U.S. Dept. of Agric. Circ. 939.

Sharpley, A. N., S. J. Smith, O. R. Jones, W. A. Berg, and G. A. Coleman. 1992. The transport of bioavailable phosphorus in agricultural runoff. J. Environ. Qual. 21:30-35.

Sharpley, A. N., T. Daniel, T. Sims, J. Lemunyon, R. Stevens, and R. Parry. 1999. Agricultural phosphorus and eutrophication. ARS-149. USDAARS, Washington, DC.
Sonzogoni, G., D. R. Chesters, D. N. Jeffs, J. C. Conrad, R. C. Osttry, and J. B. Robinson. 1980. Pollution from land runoff. Environ. Sci. Technol. 14:481-153.

Tabbara, H. 2003. Phosphorus loss to runoff water twenty-four hours after application of liquid swine manure or fertilizer. J. Environ. Qual. 32: 1044-1052.

USDA/NRCS. 1996. Soil Survey Laboratory Methods Manual. Soil Survey Investigations Report No. 42, Version No. 3. USDA-NRCS, Washington, $D C$.

USDA/NRCS. 1999. Soil Survey Geographic (SSUR GO) database for Lancaster County, Nebraska. [Online]. Available at http://www.ftw.nrcs.usda. gov/ssur_data.html. USDA, Washington, DC.

USDA/SCS. 1991. Chapter 2: Estimating Runoff and Peak Discharges. pp. 1-19. In: National Engineering Field Manual. USDA-NRCS, Washington, DC.

USEPA. 1986. Water quality criteria for water. Rep. 440/5-86-001. USEPA Office of Water, Washington, $\mathrm{DC}$.

USEPA. 1996. Clean water action plan: Restoring and protecting America's waters. USEPA, U.S. Govt. Printing Office, Washington, DC.

USGS. 2001. Platte river basin, Lower Platte River Basin, Salt Creek at Roca. pp. 180-181. In: Water resource data, Nebraska water year 2000. WaterData Report NE-00-1. US Department of the Interior, USGS, Washington, DC. 